\title{
Effect of logging wounds on diameter growth of beech (Fagus orientalis Lipsky) trees following selection cutting in Caspian forests of Iran
}

\author{
Farzam Tavankar ${ }^{1 *}$, Amireslam Bonyad ${ }^{2}$, Enrico Marchi ${ }^{3}$, Rachele Venanzi ${ }^{4}$ and Rodolfo Picchio ${ }^{4}$
}

\begin{abstract}
Background: Logging damage to residual trees during selection cutting may lead to serious economic losses in terms of both timber quality and diameter growth reduction. In this study, we investigated the effect of logging operations on residual tree damage and the consequence of injuries on diameter growth in an uneven-aged mixed forest dominated by beech (Fagus orientalis Lipsky).

Methods: The diameter growth of 56 wounded and 56 unwounded beech trees were compared 12 years after selected logging of other trees had taken place in an Iranian Caspian forest.

Results: Of total logging wounds, $25.0 \%$ (14 wounds) were caused by felling operations and $75.0 \%$ (42 wounds) were caused by winching operations. The reduction in diameter growth of wounded beech trees was only observed in the breast height DBH range below $55 \mathrm{~cm}$. The diameter growth of wounded trees was $8.1 \%$ lower than in unwounded trees. The vertical distance from the ground of wounding was a significant factor in diameter growth. Wounds that were larger than $200 \mathrm{~cm}^{2}$ in area significantly reduced diameter growth of beech trees. Whether wounds were closed or open wounds had no significant effect on diameter growth but decayed wounds reduced diameter growth by $15.3 \%$.

Conclusions: This study suggested that intensive logging wounds reduce diameter growth, especially in young beech trees. In addition to the intensity, size and position of wounds and tree age, the reduction of diameter growth was related to the ratio of wound size to stem area.
\end{abstract}

Keywords: Fagus orientalis Lipsky; Felling; Logging damage; Tree growth; Winching

\section{Background}

Impact on residual trees and/or to the regeneration of forest after forest harvesting continues to be one of the major concerns of forest managers responsible for implementing selection harvests (Reisinger and Pope 1991; Smith et al. 1994; Nikooy et al. 2010). The reduction of the negative effects of felling and extraction is one of the main goals when achieving sustainable forest management (Sist and Nguyen-Thé 2002). Skinned bark and exposed sapwood, root damage and broken branches are the most common forms of damage occurring during forest logging (Vasiliauskas and Stenlid 2007). When the bark is torn from living trees, physiological changes and cell

\footnotetext{
* Correspondence: tavankar@aukh.ac.ir

'Department of Forestry, Khalkhal Branch, Islamic Azad University, P.O. Box: 56817-31367, Khalkhal, Iran

Full list of author information is available at the end of the article
}

differentiation occur in the area surrounding the injury and callus starts to develop from the living bark towards the centre of the wound (Neely 1979). Stem wound and root damage are also potential means of entry for organisms causing decay and pitch rings (Shigo 1966; Pechmann 1974; Dimitri 1983). Because of potential decreased tree vigour and increased likelihood of attack by insects or diseases, logging injury to the remaining trees may lead to serious economic losses in terms of timber quality at the final harvest (Kiser 2011), wood losses of damaged trees and tree growth reduction (Ohman 1970; Vasiliauskas 2001).

Several studies on logging damage have highlighted that a number of factors affect the susceptibility to and effect of mechanical injury. These include the following: tree species (Bettinger and Kellogg 1993; Vasiliauskas 2001), silvicultural treatment (Bettinger et al. 1998), logging 
season (Limbeck-Lilienau 2003), logging methods (Bragg et al. 1994; Spinelli et al. 2010; Marchi et al. 2014), harvesting system (Han and Kellogg 2000), site characteristics (Sist et al. 2003), amount of timber removed during harvest (Fjeld and Granhus 1998; Gullison and Hardner 1993), design of the extraction trails (Gullison and Hardner 1993), and skill of the personnel operating the equipment (Wallentin 2007; Nikooy et al. 2010). The effect of damage on tree growth has been also investigated showing contrasting results. Some studies clearly indicated that growth losses occur in damaged trees, and in some cases, these can seriously offset the gains from harvesting (Vasiliauskas 2001). Shea (1961) recorded a reduction in diameter growth in injured Douglas-fir (Pseudotsuga menziesii (Mirb) Franco). Isomäki and Kallio (1974) verified a decrease by $35-40 \%$ in both radial and height growth in Norway spruce (Picea abies (L.) H. Karst.) trees with root collar damage following logging and a $15 \%$ reduced growth due to stem damage. Other studies showed stem wounds in Norway spruce may result in growth rate losses ranging from 14 to 25 \% (Baader 1956; Vanek 1957). In contrast, Vasiliauskas and Stenlid (2007) recorded an increase in radial growth in injured stems of ash (Fraxinus excelsior L.). Finally, a number of investigations failed to reveal any significant effect of stem wounds on the increment of Norway spruce (Vasiliauskas 1994), western hemlock (Tsuga heterophylla (Raf.) Srag.) (Shea 1961), oak (Quercus robur L.) (Vasiliauskas 1998) and Corsican pine Pinus nigra subsp. salzmanniivar. corsicana (Loudon) Hylander (as Pinus laricio Poiret) (Picchio et al. 2011). It is difficult, therefore, to make a general conclusion on what effect mechanical stem damage has on tree growth (Vasiliauskas 2001). Also, most of the studies on this topic are quite dated, mainly related to conifer species and, most importantly, approach the effect of damage on tree growth taking into consideration the effect of damage caused by animals rather than logging. Studies on this topic are still limited, especially in broadleaved stands, and the long-term effects of damage are not well known (Mäkinen et al. 2007). In order to improve logging methods, a better knowledge about the long-term impact of forest operations is needed (Whitman et al. 1997; Tavankar and Bonyad 2014).

Beech is the most industrial commercial tree species among more than 80 broadleaved trees and shrubs in the Caspian forests (Marvie-Mohadjer 2006). Pure or mixed oriental beech stands represent the most important forest communities in the natural Caspian forests (Marvie-Mohadjer 2006). These stands constitute approximately $17.6 \%$ of the area, $30 \%$ of standing volume and $23.6 \%$ of stems number in the Iranian Caspian forests (Amiri et al. 2013).
In this study, we investigated the effect of a logging operation on residual tree damage and the consequence of injuries on diameter growth in an uneven-aged mixed forest dominated by beech in the Caspian forest of Iran. In detail, the aims of this study were the following: (i) to assess the long-term effects of logging damage on both diameter growth and wound condition after 12 years since logging and (ii) to analyse the relation of intensity, size and location of injuries with beech diameter growth.

\section{Methods}

\section{Study area}

This study was conducted in parcel 35 in district 1 of Nav forests, located between $37^{\circ} 38^{\prime} 34^{\prime \prime}$ to $37^{\circ} 42^{\prime} 21^{\prime \prime}$ N $N$ and $48^{\circ} 48^{\prime} 44^{\prime \prime}$ to $48^{\circ} 52^{\prime} 30^{\prime \prime}$ E. Elevation in the study area ranged from 950 to $1350 \mathrm{~m}$ a.s.l. The mean annual precipitation is approximately $950 \mathrm{~mm}$, and the mean annual temperature is $9.1{ }^{\circ} \mathrm{C}$. The original vegetation of this area is an uneven-aged mixed forest dominated by Fagus orientalis Lipsky. The soil type is forest brown, and texture varies between sandy clay loams to clay loam. The silvicultural method applied in this forest is single selection cutting. Logging operations in the area were carried out in December 1999 and January 2000. In total, 216 marked trees $\left(6.75\right.$ trees $\left.\mathrm{ha}^{-1}\right)$ were scattered in the parcel area (32 ha), and these have a volume of $688 \mathrm{~m}^{3}\left(21.5 \mathrm{~m}^{3} \mathrm{ha}^{-1}\right)$. The diameter at breast height (DBH) of the marked trees ranged from 20 to $135 \mathrm{~cm}$. The marked trees were felled, limbed and topped at $20 \mathrm{~cm}$ dib (diameter inside bark) by chain saw. Logs, ranging from 5.2 to $7.8 \mathrm{~m}$ in length, were then extracted from the felling site to the roadside landings using a Timber-jack $450 \mathrm{C}$ wheeled skidder. The weight of the skidder was $9.8 \mathrm{t}$, and its width and length were 3.8 and $6.4 \mathrm{~m}$, respectively.

\section{Data collection and analysis}

Immediately after logging (year 2000), all wounded beech trees (56 stems) were identified, numbered and marked. The position of each damaged tree was also identified on a topographical map using the global positioning system. On each damaged tree, the following parameters were recorded after logging: diameter at breast height $(\mathrm{DBH}, 1.30 \mathrm{~m})$ and diameter at wound height (DWH) (measured by dendrometric calliper in $\mathrm{mm}$ ), damage severity (i.e. type of damaged tissues: bark, phloem, wood fibres), cause of damage (i.e. felling or extraction), and position and size of wounds. The wound size was determined by measuring the maximum length and width by a ruler ( $1 \mathrm{~mm}$ accuracy) and calculating the ellipse surface area (Picchio et al. 2011). The wound sizes were then classified in three classes: < 100, 101-200 and $>200 \mathrm{~cm}^{2}$. The position of the wound was determined with a tape measuring 
the distance between the wound centre and the ground. The position of each wound was recorded in three classes, $<0.3 \mathrm{~m}, 0.3-1 \mathrm{~m}$ and $>1 \mathrm{~m}$ (Limbeck-Lilienau 2003). A neighbouring unwounded beech tree with similar characteristics (i.e. DBH, height, vitality, crown class of all the trees-i.e. dominant, codominant subdominant, etc.) was selected for comparison with each wounded tree. After 12 years (i.e. in year 2012), the wounded and unwounded trees were identified in the parcel area, and DBH and condition of wounds were reexamined and classified in three types: closed, open and decayed (Han et al. 2000). The 12-year period diameter growth of damaged and undamaged trees was calculated using Eq. 1 (Clark and Clark 1992):

$$
\mathrm{DG}=\left(\mathrm{DBH}_{2}-\mathrm{DBH}_{1}\right) / t
$$

Where DG is diameter growth $\left(\mathrm{mm} \times\right.$ year $\left.^{-1}\right), \mathrm{DBH}_{1}$ and $\mathrm{DBH}_{2}$ are diameter at breast height at the start and end of interval $(\mathrm{mm})$, respectively, and $t$ is time interval between two measurements (years). Reduction of diameter growth was calculated using Eq. 2:

$$
\mathrm{RDG}=(\mathrm{UDG}-\mathrm{WDG}) / \mathrm{UDG}
$$

Where RDG is reduction of diameter growth, UDG is unwounded diameter growth and WDG is wounded diameter growth

After checking for normality (Kolmogorov-Smirnov test) and homogeneity of variance (Levene test), a paired $t$ test was applied to compare means of diameter growth (DG) in wounded and unwounded trees.

A non-parametric test (Spearman) was applied to test the relationship between the following: DBH vs. wound severity, wound position vs wound severity, wounded area vs. wound severity, wounded area vs. wound position, and wound position vs. DBH.

Regression analysis was applied to test the following relationships between: (i) diameter growth and tree age for both damaged and undamaged trees; (ii) wound size and tree diameter at the time of logging; (iii) diameter growth and wound position; and (iv) reduction of diameter growth and ratio of wound size to stem area. All analyses were performed using SPSS 19 software (IBM, NY, USA).

\section{Results and discussion}

Of total logging wounds, $25 \%$ (14 wounds) were caused by the felling operation and $75 \%$ ( 42 wounds) were caused by the extraction operation (Table 1). Normally, the extraction operation is considered to be one of the major sources of wounds in selection cuttings, but this view is only partially correct. During the logging operations, in particular during the felling phase, some trees marked for retention are accidentally destroyed during

\begin{tabular}{|c|c|c|c|c|c|c|}
\hline \multirow{2}{*}{$\begin{array}{l}\text { Cause of } \\
\text { wound }\end{array}$} & \multicolumn{2}{|c|}{ Closed } & \multicolumn{2}{|c|}{ Open } & \multicolumn{2}{|c|}{ Decayed } \\
\hline & $(n)$ & $(\%)$ & (n) & (\%) & (n) & (\%) \\
\hline Felling & 10 & 71.4 & 3 & 21.4 & 1 & 7.2 \\
\hline Extraction & 11 & 26.2 & 15 & 35.7 & 16 & 38.1 \\
\hline
\end{tabular}

Table 1 Frequency of wounds by cause of wound

the felling of big trees nearby. In these cases, there are no wounds on trees but only dead trees. After 12 years following wound occurrence, $71.4 \%$ of felling wounds were closed, while only $26.2 \%$ of extraction wounds were closed. The number and percentage of open and decayed extraction wounds were higher than felling wounds $-38.1 \%$ of extraction wounds were decayed after 12 years. This is a consequence of the correlation between wound position and wound severity. For the extraction wounds, normally the first metre of the stem was damaged and the wounds were large and deep, extending below the bark down into the wood. These are ideal conditions for infection by diseases in particular fungi.

Picchio et al. (2012) studied improved winching techniques designed to decrease stand damage in the forests of central Italy. They reported that the use of a snatch block decreased by one-quarter the frequency of wounded trees from 50 to $36 \%$.

The frequency of wounds for DBH classes by cause of wound is shown in Table 2. From the analysis of all the trees wounded, 4 wounds $(7.1 \%)$ were found on trees with DBH $<20 \mathrm{~cm}, 15$ wounds $(26.8 \%)$ on trees with DBH ranging from 20 to $40 \mathrm{~cm}, 24$ wounds $(42.9 \%)$ on trees with DBH ranging from 41 to $60 \mathrm{~cm}$, and 13 wounds $(23.2 \%)$ on trees with DBH $>60 \mathrm{~cm}$. In each DBH class, the frequency of extraction wounds was higher than the frequency of felling wounds. This distribution of wounded trees, with the major frequency in the two central DBH classes $(20-40 \mathrm{~cm}$ and $41-60 \mathrm{~cm}$ ) is mainly due to the structure of the uneven-aged forest. In these forests, normally there are small groups of trees coetaneous, with high density and the operation of "thinning" is more intensive in the groups of the two central DBH classes. The probability of damage depends on the felling intensity and the trees density (Picchio et al. 2012). Residually damaged trees were highly concentrated near

Table 2 Frequency of wounds for each DBH class by cause of

\begin{tabular}{|c|c|c|c|c|c|c|c|c|}
\hline \multirow{3}{*}{$\begin{array}{l}\text { Cause of } \\
\text { wound }\end{array}$} & \multicolumn{8}{|c|}{$\mathrm{DBH}(\mathrm{cm})$} \\
\hline & \multicolumn{2}{|c|}{$<20$} & \multicolumn{2}{|c|}{$20-40$} & \multicolumn{2}{|c|}{$41-60$} & \multicolumn{2}{|c|}{$>60$} \\
\hline & $(n)$ & (\%) & (n) & $(\%)$ & (n) & $(\%)$ & (n) & (\%) \\
\hline Felling & 1 & 25.0 & 2 & 13.3 & 5 & 20.8 & 6 & 46.2 \\
\hline Extraction & 3 & 75.0 & 13 & 86.7 & 19 & 79.2 & 7 & 53.8 \\
\hline
\end{tabular}
wound 
the skid trails as showed in other studies (Solgi and Najafi 2007; Ezzati and Najafi 2010).

The results of the Spearman correlation analysis are shown in Table 3 . The only statistically significant correlation was between wound severity and wound position $(P<0.01)$. In this case, the correlation was negative because the wounds closer to the ground were more severe. This is due mainly to the skidded logs impacting the standing trees and was rarely due to the impact of the trees with the tractor.

The average annual growth of wounded and unwounded beech trees after 12 years is shown in Table 4 . Overall, there was no significant difference $(P>0.05)$ in the diameter increment of wounded trees compared with unwounded trees. In detail, the reduction of diameter growth in wounded beech trees was related only to wound size, severity and condition but only for some specific typologies of wounds characteristics. In order of importance, wounds $>200 \mathrm{~cm}^{2}$ led to greatest reduction of diameter growth $(29.3 \% ; P<0.05)$, followed by the wound condition, defined as "decayed", (which caused a RDG of $15.3 \%(P<0.001))$ and lastly the depth of the wound. When the damage has affected the wood fibres, the average RDG was $13.2 \%(P<0.001)$. Also for a Norway spruce forest, width and depth of the logging injury correlated positively with the decrease in growth (Isomäki and Kallio 1974).

Wound size is one of the most important characteristics related to decay (Hunt and Krueger 1962; Han and Kellogg 2000). As found also by Vasiliauskas (2001), most of the resulting wounds occur near the base of the tree and are up to $200 \mathrm{~cm}^{2}$ in size. Since logging injury usually occurs on the lower parts of trunk, wound decay in a tree affects the most valuable timber (Picchio et al. 2011; Tavankar et al. 2013).

Of all wounds recorded on beech trees, $55.3 \%$ (31 wounds) occurred at a height lower than $0.3 \mathrm{~m}$ from the ground, $26.8 \%$ (15 wounds) occurred between 0.3 to $1 \mathrm{~m}$ height and $17.9 \%$ (10 wounds) occurred at a height higher than $1 \mathrm{~m}$.

The results of this study indicated that most skidderlogging wounds $(55.3 \%)$ occurred in the near ground level of the bole $(<0.3 \mathrm{~m})$ and were associated with a

Table 3 Results of Spearman correlation analysis

\begin{tabular}{lcll}
\hline Variables & N & $\begin{array}{l}\text { Correlation } \\
\text { coefficient }\end{array}$ & Sig. (2-tailed) \\
\hline DBH vs. wound severity & 56 & 0.025 & 0.853 \\
DBH vs. wound position & 56 & 0.042 & 0.751 \\
Wound size vs. wound position & 56 & 0.131 & 0.336 \\
Wound size vs. wound severity & 56 & -0.018 & 0.893 \\
Wound position vs. wound severity & 56 & -0.747 & $0.000^{* *}$ \\
\hline
\end{tabular}

${ }^{* *} a=0.01$.
$10.7 \%$ reduction in diameter growth relative to unwounded trees. The location of wounds from groundbased logging operations observed in this study is consistent with results from other published studies (Naghdi et al. 2008; Tavankar et al. 2011). The higher incidence of damage near the base of the tree is important because the butt $\log$ is generally the most valuable $\log$ in a tree (Bettinger and Kellogg 1993). Han and Kellogg (2000) suggested that artificial tree protection rigging such as rub pads along extraction corridors should be used to prevent damage on stump and stems.

Twelve years after the trees were wounded, $37.5 \%$ of wounds were completely healed, $32.1 \%$ were still open and $30.4 \%$ were decayed. Trees with decayed wounds showed significant reduced diameter growth in comparison with undamaged ones $(P<0.01)$.

The multiple regression analyses applied to test the relationship between diameter growth and tree DBH (closely related to age) of both wounded and unwounded were statistically significant $(P<0.001)$. The results are shown in Eq. 2 and Fig. 1:

$$
\mathrm{DG}=8.27-(0.037 \times \mathrm{DBH})-(0.415 \times \mathrm{TC})
$$

$\left(R^{2}\right.$ adjusted $\left.=0.162 ; \mathrm{SE}=1.521\right)$

Where DG is the diameter growth of tree $\left(\mathrm{mm} \mathrm{year}^{-1}\right)$, and TC is the tree condition ( 0 for unwounded and 1 for wounded).

Diameter growth of wounded trees was lower than for unwounded trees in small trees $(\mathrm{DBH}<55 \mathrm{~cm})$, and the greater the tree diameter the smaller the differences. Thus, growth of wounded and unwounded trees was similar when DBH was greater than $55 \mathrm{~cm}$.

The regression analysis between wound size and tree diameter at the time of logging was also statistically significant $(P<0.001)$, and the results are shown in Eq. 3 and Fig. 2:

$$
\text { WS }=72.6 * \ln (\mathrm{DBH})-128.6
$$

$\left(R^{2}\right.$ adjusted $\left.=0.373 ; \mathrm{SE}=45.37\right)$

Where WS is the wound size. Only $37.3 \%$ of the variability of the wound size was explained by DBH.

The regression analysis showed diameter growth of wounded trees increased with increasing wound position (height from ground level), (Fig. 3).

The results of the regression analysis between DG of wounded trees and wound position (WP) indicated two different situations depending on wound position. Thus, the relationship was significant for wounds positioned below $0.5 \mathrm{~m}$ of height (Fig. 3 and Eq. $4 ; R^{2}$ adjusted $=0.95$; $\mathrm{SE}=0.24 ; \mathrm{F}=579.7, P<0.01$ ), but there was no relationship between DG and wounds positioned over $0.5 \mathrm{~m}$ from ground level $\left(R^{2}\right.$ adjusted $\left.=0.25, F=6.99, P<0.05\right)$. 
Table 4 Mean \pm SD of diameter growth of unwounded, wounded and reduction of diameter growth (RDG) of beech trees 12 years after wound occurrence in related to wounds characteristics

\begin{tabular}{|c|c|c|c|c|c|c|}
\hline Wounds characteristic & $n$ paired & Unwounded (mm.year $\left.{ }^{-1}\right)$ & Wounded (mm.year ${ }^{-1}$ ) & RDG (\%) & $t$ paired & $P$ value \\
\hline \multicolumn{7}{|l|}{ Wound position (m) } \\
\hline$<0.3$ & 31 & $6.63 \pm 1.8$ & $5.92 \pm 1.8$ & 10.7 & 1.48 & 0.148 \\
\hline $0.3-1$ & 15 & $6.66 \pm 0.6$ & $6.06 \pm 1.4$ & 9.9 & 1.64 & 0.124 \\
\hline$>1$ & 10 & $6.35 \pm 2.2$ & $6.45 \pm 0.9$ & -1.6 & 0.18 & 0.862 \\
\hline \multicolumn{7}{|l|}{ Wound size $\left(\mathrm{cm}^{2}\right)$} \\
\hline$<100$ & 9 & $5.96 \pm 1.1$ & $5.93 \pm 0.9$ & 0.5 & 0.04 & 0.966 \\
\hline $101-200$ & 31 & $6.25 \pm 1.2$ & $6.20 \pm 1.0$ & 0.8 & 0.24 & 0.812 \\
\hline$>201$ & 16 & $7.36 \pm 1.5$ & $5.21 \pm 2.1$ & 29.3 & $2.92^{*}$ & 0.010 \\
\hline \multicolumn{7}{|l|}{ Wound severity } \\
\hline Bark & 9 & $6.74 \pm 0.9$ & $6.72 \pm 0.9$ & 0.3 & 0.03 & 0.972 \\
\hline Phloem & 14 & $6.50 \pm 0.9$ & $6.46 \pm 1.1$ & 0.6 & 0.07 & 0.871 \\
\hline Wood & 33 & $6.60 \pm 1.1$ & $5.73 \pm 1.4$ & 13.2 & $4.22^{* *}$ & 0.000 \\
\hline \multicolumn{7}{|l|}{ Wound condition } \\
\hline Healed & 21 & $6.72 \pm 0.8$ & $6.60 \pm 1.0$ & 1.8 & 1.27 & 0.217 \\
\hline Still open & 18 & $6.67 \pm 1.0$ & $5.88 \pm 1.4$ & 11.8 & 1.94 & 0.069 \\
\hline Decayed & 17 & $6.54 \pm 1.0$ & $5.54 \pm 1.5$ & 15.3 & $5.48^{* *}$ & 0.000 \\
\hline All trees & 56 & $6.59 \pm 1.65$ & $6.05 \pm 1.54$ & 8.1 & 1.80 & 0.078 \\
\hline
\end{tabular}

$\mathrm{DG}=1.09+28.46 \times \mathrm{WP}$

Where DG is diameter growth $\left(\mathrm{mm}_{\text {.year }}{ }^{-1}\right)$ and WP is wound position $(\mathrm{m})$ from the ground level.

This result suggests that the severity of wounds increased with decreasing height from ground level and/or due to an increased likelihood of pathogen attack in wounds close to ground level.

The regression analysis between the reduction of diameter growth and ratio of wound size to stem area is shown in Fig. 4. The results indicated that the reduction of diameter growth increased with increasing ratio of wound size to stem area above $0.1(F=24.9, P<0.01)$.
The results of regression analysis are shown following equation:

$$
\text { RDG\% }=491.07(\text { RWS })^{2}-87.81(\text { RWS })+6.75
$$

$\left(R^{2}\right.$ adjusted $\left.=0.51 ; \mathrm{SE}=4.62\right)$

Where RDG is the reduction of diameter growth and RWS is the ratio of wound size to stem area.

This study evaluated the effect of logging wounds on diameter growth of standing beech trees in the Caspian forest 12 years after selection logging. Pre-harvest planning and identification of the winching area before logging operation commences can reduce damage to the

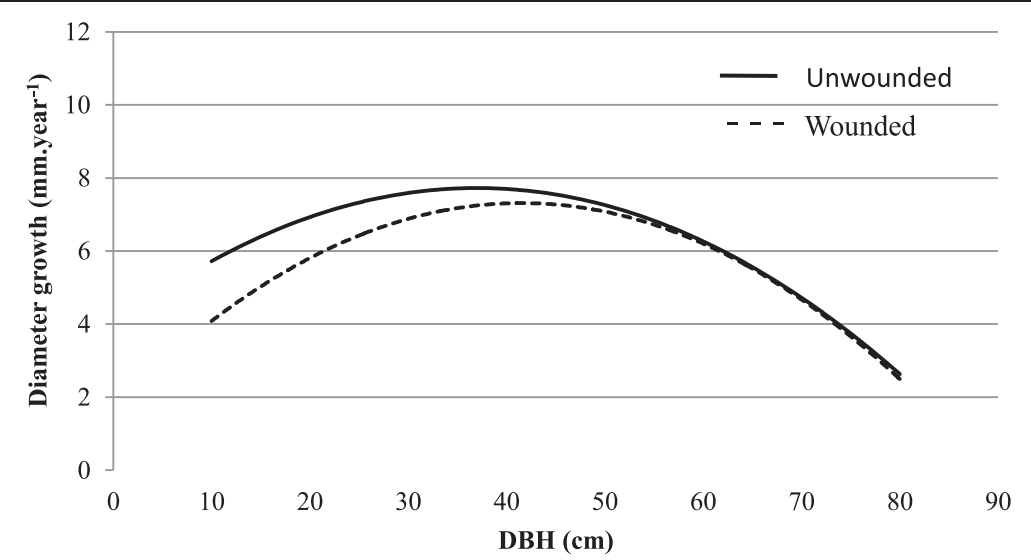

Fig. 1 Relationship between annual diameter growth of wounded and unwounded trees and their DBH in the year 2000 


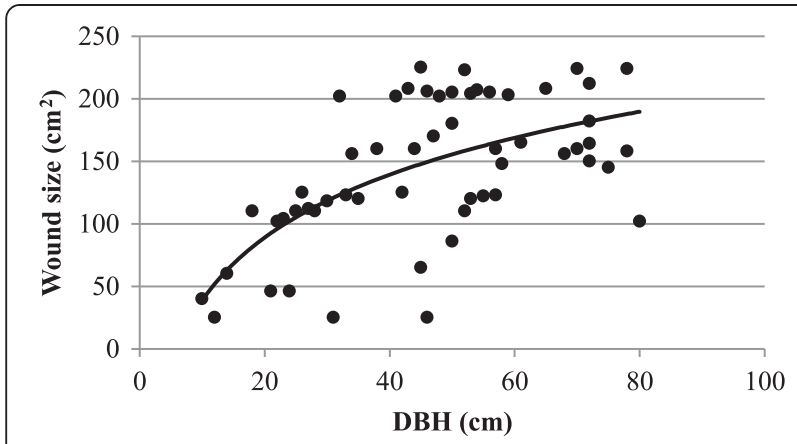

Fig. 2 Relationship between DBH of wounded trees in the year 2000 and wound size

standing trees in these forests. Also, skid-trail planning before a felling operation can reduce the skidding damage (Naghdi et al. 2008; Majnounian et al. 2009). The skidder and chain saw operators are important factors that can influence productivity and environmental impacts during logging operations. It has been reported that residual stand damage decreases substantially by careful planning and skilful operators (Cline et al. 1991; Pinard et al. 30). Nikooy et al. (2010) reported that skilled operation of a skidder can decrease the level of damage. So training of forest workers can be useful to reducing logging damage to the residual stand. All workers should be made aware of the purpose of the selection cutting and that both minor and major injuries to the residual stands as well as excessive ground disturbance may result in significant volume losses (Davis and Nyland 1991) and natural regeneration of the forest (Picchio et al. 2012).

\section{Conclusions}

This study shows that logging wounds cause a substantial reduction $(8.1 \%)$ in diameter growth of residual trees left after a selective logging operation. Our results showed that the effect of bole wounds on diameter growth depended on their severity, location and size, and tree age. Young beech trees were more sensitive to

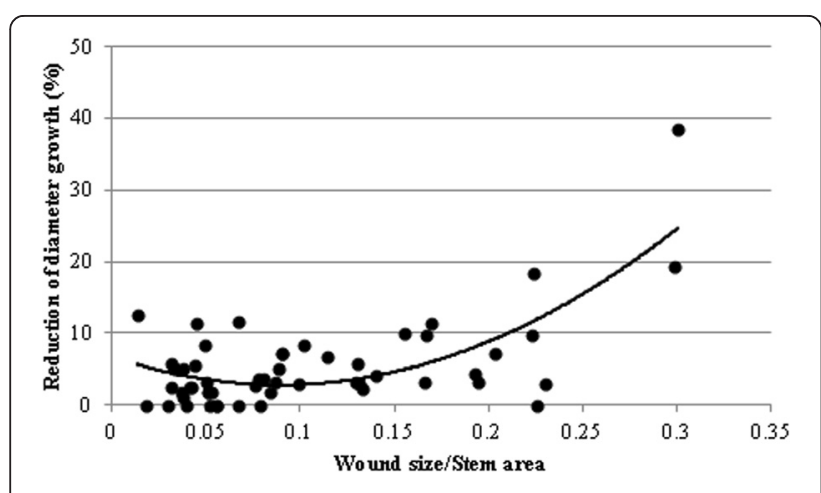

Fig. 3 Relationship between diameter growth and wound position

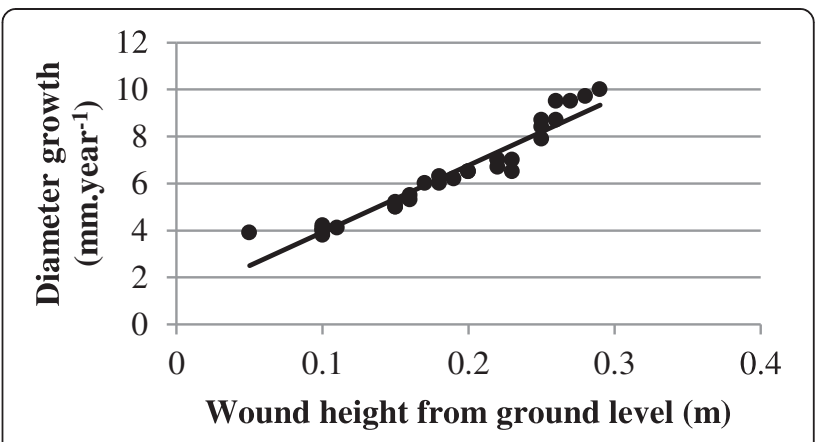

Fig. 4 Relationship between reduction of diameter growth and ratio of wound size to stem area

logging wounds. Residual stand damage is an unavoidable risk of selection cutting, but the level of damage should be minimised to assure quality timber from future harvests. The results of this study indicated also that tree extraction has a high potential for residual stand damage, and intensive wounds occurred during extraction operations. It is important to minimise damage, both to the number of trees damaged and the extent of damage to any individual tree.

\section{Competing interests}

The authors declare that they have no competing interests.

\section{Authors' contributions}

All authors read and approved the final manuscript.

\section{Author details}

${ }^{1}$ Department of Forestry, Khalkhal Branch, Islamic Azad University, P.O. Box: 56817-31367, Khalkhal, Iran. ²Department of Forestry, Faculty of Natural Resources, University of Guilan, P.O. Box: 1144, Somehsara, Iran. ${ }^{3}$ Department of Agriculture, Food and Forest Systems, Florence University, Via San Bonaventura, 1350145 Florence, Italy. ${ }^{4}$ Department of Science and Technology for Agriculture, Forest, Nature and Energy (DAFNE), Tuscia University, Via S. Camillo De Lellis, 01100 Viterbo, Italy.

Received: 15 March 2015 Accepted: 11 October 2015

Published online: 29 October 2015

\section{References}

Amiri, M, Rahmani, R, Sagheb-Talebi, K, \& Habashi, H. (2013). Dynamic and structural characteristics of a natural unlogged oriental beech (Fagus orientalis Lipsky) stand during a 5-year period in Shast Kalate forest, northern Iran. The International Journal of Environmental Resources Research, 1(2), 107-29.

Baader, G. (1956). Damage by game in Rheinland-Pfalz and the possibilities to minimize it. Allgemine Forest Jagdztg, 127, 233-40.

Bettinger, P, \& Kellogg, L. (1993). Residual stand damage from cut-to-length thinning of second growth timber in the Cascade Range of western Oregon. Forest Products Journal, 43, 59-64.

Bettinger, P, Bettinger, KA, \& Boston, K. (1998). Correlation among spatial and non-spatial variables describing a cut-to-length thinning site in the Pacific Northwest, USA. Forest Ecology and Management, 104, 139-49. doi:10.1016/s0378-1127(97)00250-8.

Bragg, W, Ostrofsky, W, \& Hoffman, B. (1994). Residual tree damage estimates from partial cutting simulation. Forest Products Journal, 44, 19-22.

Clark, DA, \& Clark, DB. (1992). Life history diversity of canopy and emergent trees in a neotropical rain forest. Ecological Monographs, 62, 315-44.

Cline, ML, Hoffman, BF, Cyr, M, \& Bragg, W. (1991). Stand damage following whole-tree partial cutting in Northern forests. Northern Journal of Applied Forestry, 8, 72-6. 
Davis, CJ, Nyland, RD. (1991). Designated skid trails: results after 18 years. American Society of Agricultural Engineers, ASAE winter meeting, December 1720, 1991, Chicago Illinois. [Paper No. 917522].

Dimitri, L. (1983). Wound decay following tree injury in forestry: establishment, significance and possibilities of its prevention. Forstwissenschaftliches Centralblatt, 102, 68-79.

Ezzati, S, \& Najafi, A. (2010). Long-term impact evaluation of ground-base skidding on residual damaged trees in the Hyrcanian Forest, Iran. International Journal of Forestry Research, 1, 1-8. doi:10.1155/2010/183735.

Fjeld, D, \& Granhus, A. (1998). Injuries after selection harvesting in multistoried spruce stands-the influence of operating systems and harvest intensity. International Journal of Forest Engineering, 9(2), 33-40. doi:10.1080/08435243.1998.10702716.

Gullison, R, \& Hardner, J. (1993). The effects of road design and harvest intensity on forest damage caused by selective logging: empirical results and a simulation model from the Bosque Chimanes, Bolivia. Forest Ecology and Management, 59, 1-14. doi:10.1016/0378-1127(93)90067-W.

Han, HS, \& Kellogg, LD. (2000). Damage characteristics in Young Douglas-fir stand from commercial thinning with four timber harvesting systems. Western Journal of Applied Forestry, 15, 27-33.

Han, HS, Kellogg, LD, Fillip, GM, \& Brown, TD. (2000). Scar closure and future timber value losses from thinning damage in western Oregon. Forest Products Journal, 50, 36-42.

Hunt, J, \& Krueger, KW. (1962). Decay associated with thinning wounds in younggrowth western hemlock and Douglas-fir. Journal of Forestry, 60, 336-40.

Isomäki, A, \& Kallio, T. (1974). Consequences of injury caused by timber harvesting machines on the growth and decay of spruce (Picea abies $L$. Karst.). Acta Forest Fennica, 136, 1-25.

Kiser, J. (2011). Histochemical and geometric alterations of sapwood in costal Douglas-fir following mechanical damage during commercial thinning. Silva Fennica, 45(4), 729-41.

Limbeck-Lilienau, B. (2003). Residual stand damage caused by mechanized harvesting systems. In T Steinmuller \& K Stampfer (Eds.), Proceedings of high tech forest operations for mountainous terrain. 5-9 Oct. Schlaegl-Austro, 2003. Vienna: University of Natural Resources and Life Sciences.

Majnounian, B, Jourgholami, M, Zobeiri, M, \& Feghhi, J. (2009). Assessment of forest harvesting damage to residual stands and regenerations-a case study of Namkhaneh District in Kheyrud Forest. Journal of Environmental Sciences, 7(1), 33-44.

Mäkinen, H, Hallaksela, AM, \& Isomäki, A. (2007). Increment and decay in Norway spruce and Scots pine after artificial logging damage. Canadian Journal of Forest Research, 37, 2130-41. doi:10.1139/X07-087.

Marchi, E, Picchio, R, Spinelli, R, Verani, S, Venanzi, R, \& Certini, G. (2014). Environmental impact assessment of different logging methods in pine forests thinning. Ecological Engineering, 70, 429-36. doi:10.1016/j.ecoleng.2014.06.019.

Marvie-Mohadjer, M. (2006). Silviculture. Tehran: Tehran University publishing.

Naghdi, R, Rafatnia, N, Bagheri, I, \& Hemati, V. (2008). Evaluation of residual damage in felling gaps and extraction routes in single selection method (Siyahkal forest). Iranian Journal of Forest and Poplar Research, 16(1), 87-98,

Neely, D. (1970). Healing of wounds on trees. Journal of the American Society for Horticultural Science, 95, 536-40.

Nikooy, M, Rashidi, R, \& Kocheki, G. (2010). Residual trees injury assessment after selective cutting in broadleaf forest in Shafaroud. Caspian Journal of Environmental Sciences, 8(2), 173-9.

Ohman, JH. (1970). Value loss from skidding wounds in sugger maple and yellow birch. Journal of Forestry, 68, 226-30.

Pechmann, HV. (1974). The influence of thinning methods on the quality of timber. Forstarchiv, 45, 34-8.

Picchio, R, Neri, F, Maesano, M, Savelli, S, Sirna, A, Blasi, S, Baldini, S, \& Marchi, E. (2011). Growth effects of thinning damage in a Corsican pine (Pinus laricio Poiret) stand in central Italy. Forest Ecology and Management, 262, 237-43. doi:10.1016/j.foreco.2011.03.028

Picchio, R, Magagnotti, N, Sirna, A, \& Spinelli, R. (2012). Improved winching technique to reduce logging damage. Ecological Engineering, 47, 83-6. doi:10.1016/j.ecoleng.2012.06.037.

Pinard, MA, Putz, FE, Tay, J, \& Sullivan, TE. (1995). Creating timber harvesting guidelines for a reduced impact logging project in Malaysia. Journal of Forestry, 39, 41-5.

Reisinger, TW, \& Pope, PE. (1991). Impact of timber harvesting on residual trees in a central hardwood forest in Indiana. Proceedings of 8th Central Hardwood Forest Conference, 1991 March 4-6, (pp. 82-91). Newtown Square, PA: U.S.
Department of Agriculture, Forest Service, Northeastern Forest Experiment Station.

Shea, KR. (1961). Deterioration resulting from logging injury in Douglas-fir and Western hemlock. [Forest Research Note, 36, 1-5]. Federal Way, WA, USA: Weyerhaeuser Company.

Shigo, AL. (1966). Decay and discoloration following logging wounds on northern hardwoods. [USDA Research Paper, 47, 1-43]. Washington, DC: United States Department of Agriculture.

Sist, P, \& Nguyen-Thé, N. (2002). Logging damage and the subsequent dynamics of a dipterocarp forest in East Kalimantan (1990-1996). Forest Ecology and Management, 165, 85-103. doi:10.1016/s03781127(01)00549-1.

Sist, P, Sheil, D, Kartawinata, K, \& Priyadi, H. (2003). Reduced-impact logging in Indonesian Borneo: some results confirming the need for new silvicultural prescriptions. Forest Ecology and Management, 179, 415-27. doi:10.1016/S0378-1127(02)00533-9.

Smith, HC, Miller, GW, \& Schuler, TM. (1994). Closure of logging wounds after 10 years. USDA Tech Bull, 692, 1-6.

Solgi, A, \& Najafi, A. (2007). Investigating of residual tree damage during groundbased skidding. Pakistan Journal of Biological Sciences, 10, 1755-8. doi:10.3923/pjbs.2007.1755.1758.

Spinelli, R, Magagnotti, N, \& Nati, C. (2010). Benchmarking the impact of traditional small-scale logging systems used in Mediterranean forestry. Forest Ecology and Management, 260, 1997-2001. doi:10.1016/j.foreco.2010.08.048.

Tavankar, F, \& Bonyad, A. (2014). Long-term effects of logging damages on quality of residual trees in the Asalem Nav forest. Journal of Environmental Studies, 40(1), 39-50.

Tavankar, F, Bonyad, A, \& Majnounian, B. (2011). Investigation of damages to stand caused by selection cutting using skidding system in the Asalem-Nav forest, Iran. Journal of Environmental Studies, 37(3), 89-98.

Tavankar, F, Majnounian, B, \& Bonyad, A. (2013). Felling and skidding damage to residual trees following selection cutting in Caspian forests of Iran. Journal of Forest Science, 59(5), 196-203.

Vanek, J. (1957). Study on the consequences of bark stripping damage caused by game in forest stands. Lesnictvi, 3, 59-78.

Vasiliauskas, R. (1994). Wound healing rate and its influence spread of decay in spruce. Proceeding of the Lithuanian Forest Research Institute, 34, 207-12.

Vasiliauskas, R. (1998). Patterns of wounding and decay in stems of Quercus robur due to bark peeling. Scandinavian Journal of Forest Research, 13, 437-41. doi:10.1080/02827589809383004.

Vasiliauskas, R. (2001). Damage to trees due to forestry operations and its pathological significance in temperate forest: a literature review. Forestry, 74, 319-36. doi:10.1093/forestry/74.4.319.

Vasiliauskas, A, \& Stenlid, J. (2007). Discoloration following bark stripping wounds on Fraxinus excelsior. European Journal Forest Pathology, 28(6), 383-90. doi:10.1111/j.1439-0329.1998.tb01192.x.

Wallentin, C. (2007). Thinning of Norway spruce. PhD Thesis. Sueciae, Sweden: Acta Universitatis Agriculture.

Whitman, AA, Brokaw, VLN, \& Hagan, JM. (1997). Forest damage caused by selection logging of mahogany (Swietenia machrophylla) in northern Belize. Forest Ecology and Management, 92, 87-96. doi:10.1016/50378-1127(96)03941-2.

\section{Submit your manuscript to a SpringerOpen ${ }^{\odot}$ journal and benefit from:}

- Convenient online submission

$\checkmark$ Rigorous peer review

- Immediate publication on acceptance

- Open access: articles freely available online

- High visibility within the field

- Retaining the copyright to your article

Submit your next manuscript at $\boldsymbol{\triangleright}$ springeropen.com 